Ocean Sci. Discuss., 4, 399-414, 2007

www.ocean-sci-discuss.net/4/399/2007/

(C) Author(s) 2007. This work is licensed

under a Creative Commons License.
LIDAR vs. GEODAS data in hurricane inundation modelling

M. Peng et al.

\section{LIDAR vs. GEODAS land elevation data in hurricane induced inundation modelling}

M. Peng ${ }^{1}$, L. J. Pietrafesa ${ }^{2}$, S. Bao ${ }^{1}$, H. Liu ${ }^{1}$, M. Xia ${ }^{1}$, and T. Yan ${ }^{1}$

${ }^{1}$ Department of Marine, Earth and Atmospheric Sciences, North Carolina State University, Raleigh, North Carolina, Raleigh, NC, 27695, USA

${ }^{2}$ College of Physical \& Mathematical Sciences, North Carolina State University, Raleigh, North Carolina, Raleigh, NC, 27695, USA

Received: 10 April 2007 - Accepted: 16 April 2007 - Published: 26 April 2007

Correspondence to: M. Peng (mpeng@ncsu.edu)

\section{Title Page}

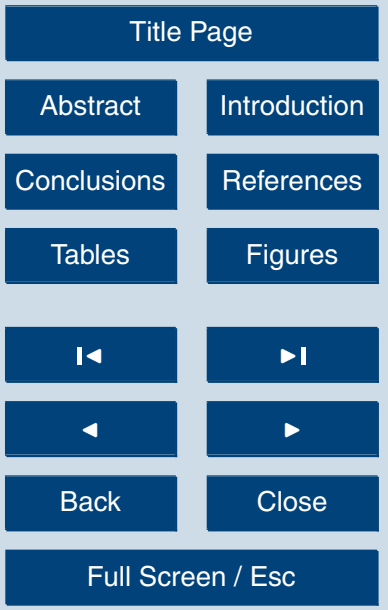

Printer-friendly Version

Interactive Discussion 


\section{Abstract}

LIDAR (Light Detection and Ranging) and GEODAS (GEOphysical DAta System) are respectively taken as the land elevation data for a 3-D storm surge and inundation model to investigate the subsequent inundation differences. Hilton Head, South Car5 olina, and Croatan-Albemarle-Pamlico Estuary System (CAPES), North Carolina, are the two investigated regions. Significant inundation differences with LIDAR versus GEODAS are found in both regions. The modeled inundation area with GEODAS is larger than with LIDAR. For Category 2-3 hypothetical hurricanes, the maximum inundation difference in Hilton Head region is $67 \%$, while the difference in the CAPES is

for the inundation difference. Recently constructed man-made structures, not included in the GEODAS, but included in the LIDAR data sets may be another contributing reason.

\section{Introduction}

15 Land elevation and bathymetry data are important to storm surge and inundation diagnostic study and may be highly important to real time forecasting. If sea-land boundary is fixed, as in most primitive storm surge models, bathymetry and elevation data are the only required topographic predetermined inputs. If inundation is a major concern (Hubbert and Malnnes, 1999; Peng et al., 2004; Oey, 2005; Peng et al., 2006b), the accuracy of the land elevation data is crucial to the model results. At present, bathymetry and land elevation data are respectively provided by the National Oceanic and Atmospheric Administration (NOAA) and United States Geological Survey (USGS). For convenience, National Geophysical Data Center (NGDC) of NOAA merged the two databases into GEOphysical DAta System (GEODAS). Generally, coastal offshore bathymetry data with a vertical precision of $0.1 \mathrm{~m}$ meets the requirement of storm surge models. More precise land elevation data, on the other hand, is desirable and nec-
OSD

4, 399-414, 2007

\section{LIDAR vs. GEODAS data in hurricane inundation modelling}

M. Peng et al.

\section{Title Page}

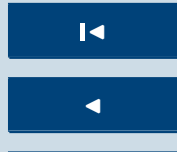

\section{Full Screen / Esc}

Printer-friendly Version

Interactive Discussion 
essary for the level of accuracy in inundation modeling needed by coast emergency managers and NOAA National Weather Service forecasters.

The accuracy of the digital elevation models (DEM) created by the USGS, the agency which is the source of land elevation data for GEODAS, depends on the source data 5 used for its production. Traditionally, DEM were derived via the photogrammetric technique, and thus the USGS DEM vertical precision is taken to be optimally $1 \mathrm{~m}$, with accuracy of $\leq 15 \mathrm{~m}$ (USGS, 1998).

Generally, two approaches are employed to handle flooding. The first is an off-line approach while the second is an interactive one. In the first approach, the area of inun10 dation is computed off-line by comparing the water level to the nearby land elevation. This off-line approach for inundation computation was employed in early storm surge modeling (e.g., Flather and Heaps, 1975; Falconer and Owens, 1987). In the second approach, the inundation is processed interactively in the model. The moving speed of flooding may be based on vertically averaged current (Hubbert and Mcinnes, 1999), or on the three dimensional flow field (Xie et al., 2004), or on the corresponding gravity wave speed with terrain features (Peng et al., 2006b). The accuracy of land elevation data is more meaningful for this approach. It determines not only if a land grid point will be inundated but also how fast the inundation process takes place.

Given the typical scale of hurricane induced storm surge and model spatial scales 20 of the order of $10 \mathrm{~s}$ of meters laterally and several centimeters vertically, land elevation data from GEODAS may not be sufficient to meet the requirements of interactive inundation modeling. LIDAR data is an attractive alternative technology. LIDAR is a remote sensing system (generally for mapping the instrument is used in an aircraft) used to collect topographic data. This technology is being used by NOAA to docu25 ment topographic changes along the U.S. shorelines. These data are collected with aircraft-mounted lasers with a vertical precision of $0.15 \mathrm{~m}$.

The purpose of this study is to assess the inundation difference as LIDAR and GEODAS are separately taken as the land elevation data under different hurricane conditions. A three dimensional interactive storm surge and inundation model is employed
OSD

4, 399-414, 2007

\section{LIDAR vs. GEODAS data in hurricane inundation modelling}

M. Peng et al.

Title Page 
in the study. Two coastal domains with high quality LIDAR data along the eastern US coast are chosen as the study regions.

OSD

4, 399-414, 2007

\section{Study regions}

LIDAR Bare Earth (canopy and structure have been subtracted) land elevation data 5 are not generally available for the eastern seaboard of the U.S. However, Hilton Head, South Carolina, and the Croatan-Albemarle-Pamlico Estuary System (CAPES), North Carolina, are two coastal sub-regions in which both GEODAS and LIDAR data are available and will be used in the study (Fig. 1). Hilton Head LIDAR data were acquired from the NOAA Coastal Services Center (CSC) in Charleston, SC which is 10 responsible for the NOAA Topographic Change Mapping for the US coast regions. The LIDAR data used in the modeling of the CAPES were obtained at great cost of digitization manpower via the North Carolina Floodplain Mapping Program (http: //www.ncfloodmaps.com). These LIDAR data are interpolated and merged onto the 3-arc-second GEODAS grid points in the regions. The two domains, both shown in 15 Fig. 1, are the respective inner domains of the corresponding 3-ring, one-way model nesting system (Peng at al., 2006b).

The land elevation differences (GEODAS subtracted from LIDAR) of the two regions are shown in Fig. 2. Generally, the LIDAR land elevation is larger than GEODAS, and the difference is less than $5 \mathrm{~m}$. The elevation difference along the shoreline may 20 reflect newly man-made structures that are not considered in the GEODAS, e.g., along the Hilton Head Island coast in Fig. 2a, and along the Outer Banks (the chain barrierislands enclosing the CAPES) in Fig. $2 \mathrm{~b}$. In most areas, the difference may have arisen from the different vertical precision of the two databases, as previously mentioned. For example, the land elevation to the west of Alligator River as depicted in GEODAS is 25 homogenously $0 \mathrm{~m}$, which is apparently not the case as suggested by the LIDAR data. These land elevation differences will inevitably induce model inundation differences that will be demonstrated later.

\section{LIDAR vs. GEODAS data in hurricane inundation modelling}

M. Peng et al.

\section{Title Page}




\section{Numerical inundation and wind models}

The 3-D interactive inundation model in Xie et al. (2004) is employed in the study. Their inundation scheme, with surface current utilized as the inundation speed control, is suitable to the region of the CAPES, a nearly closed estuary (Pietrafesa et. al., 1986). 5 However, it is not suitable to Hilton Head region. For an open coast, like Hilton Head region, this scheme may in some cases underestimate inundation (Peng et al., 2006b), and the function $C_{t}(g d)^{1 / 2}$ has been proven to be more accurate as the inundation control, where $C_{t}$ is a terrain parameter, $g$ and $d$ are respectively the gravitational acceleration and water depth. As the latter option has been shown to be appropriate 10 for all kinds of coastal regions, this inundation scheme will be employed in both Hilton Head and the CAPES domains. Following Peng et al. (2006b), the terrain parameter, $C_{t}$, is set to 0.5 in this study.

The Holland (1980) parametric wind model is used to generate the representative hurricane wind fields. As the purpose of this study is to assess the inundation difference 15 with the two land elevation databases, the parametric model generated symmetric wind forcing will not be corrected as recommended in Peng et al. (2006a). The air pressure and circular wind velocity distributions are:

$P=P_{c}+\left(P_{n}-P_{c}\right) \exp \left(-A / r^{B}\right)$

$V_{w}^{\prime}=\left[A B\left(P_{n}-P_{c}\right) \exp \left(-A / r^{B}\right) /\left(\rho r^{B}\right)\right]^{1 / 2}$

20 where $\rho$ is the air density, $P$ is the atmospheric pressure at radius $r, P_{C}$ is the hurricane central pressure, $P_{n}$ is the ambient pressure, $A$ and $B$ are scaling parameters, and $V_{w}^{\prime}$ is the hurricane pressure gradient induced wind velocity. Those parameters are set to: $P_{n}=1010 \mathrm{mb}, \rho=1.2 \mathrm{~kg} / \mathrm{m}^{3}, B=1.9, A=\left(R_{\max }\right)^{B}$, where $R_{\max }$ is the radius of maximum wind (RMW), which is set to $50 \mathrm{~km}$ for all hypothetical hurricanes (Hsu and Yan, 1998). 25 The wind speed used in this study is the combination of (2) and hurricane translation
OSD

4, 399-414, 2007

LIDAR vs. GEODAS data in hurricane inundation modelling

M. Peng et al.

Title Page

Abstract Introduction

Conclusions

Tables References

Figures

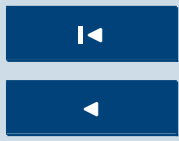

Back

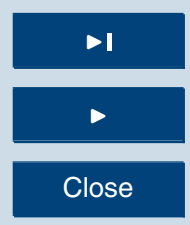

Full Screen / Esc

Printer-friendly Version

Interactive Discussion 
speed $V_{H}$ :

$V_{w}=\overrightarrow{V_{w}^{\prime}}+\overrightarrow{V_{H}}$

Hurricane wind stress is computed using the conventional bulk formula:

$\tau=\rho C_{d}\left|\overrightarrow{V_{w}}\right| \overrightarrow{V_{w}}$

5 where $C_{d}$ is the drag coefficient, which follows Large and Pond (1981) when the wind speed is less than $26.0 \mathrm{~m} \mathrm{~s}^{-1}$, and is capped at $2.16 \times 10^{-3}$ as suggested in Powell (2003) when winds exceed $26 \mathrm{~ms}^{-1}$.

\section{OSD}

4, 399-414, 2007

LIDAR vs. GEODAS data in hurricane inundation modelling

M. Peng et al.

For the Hilton Head region, all hypothetical hurricanes make landfall at Hilton Head 10 Island and travel northwestward. There are 5 cases with central pressure ranging from 965 to $945 \mathrm{mb}$. The translation speed remains $30 \mathrm{~km} \mathrm{~h}^{-1}$ for all cases. For each case, the simulation starts as the hurricane is $300 \mathrm{~km}$ before making landfall. The $965-\mathrm{mb}-$ hurricane induced overall maximum inundations with LIDAR and GEODAS data are respectively shown in Fig. $3 a$ and Fig. 3b.

15 The inundation area with GEODAS is larger than with LIDAR. The difference is clear along the Hilton Head Island coast, and it is more pronounced along the coast of Calibogue Sound and in the northern Beaufort River regions. The inundation area simulated with GEODAS is $67 \%$ more than with LIDAR. The inundation difference gets smaller as hurricane intensity increases. This trend is demonstrated in Table. 1, which

20 lists the total number of inundated grid points with LIDAR or GEODAS and their difference for each hurricane case. For instance, when the hypothetical hurricane's central pressure drops to $950 \mathrm{mb}$, the inundation difference with the two land elevation data decreases to $25 \%$. The corresponding inundation distribution is illustrated in Fig. 4.

For the CAPES region, all hypothetical hurricanes travel northward along $76.0^{\circ} \mathrm{W}$. 25 There are 4 cases with hurricane translation speed varying from $20-35 \mathrm{~km} \mathrm{~h}^{-1}$. The 404
Title Page

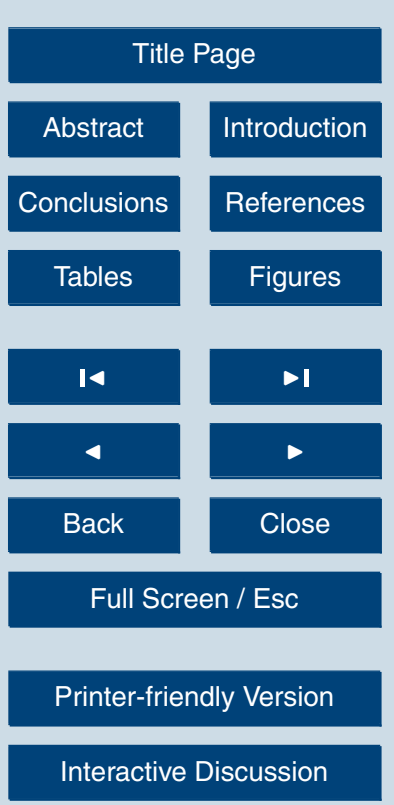

EGU 
central pressure for all hurricanes remains at $960 \mathrm{mb}$. Model simulation starts at $32.0^{\circ} \mathrm{N}$ for all cases. The inundation distributions with LIDAR and GEODAS data for the $30 \mathrm{~km} \mathrm{~h}^{-1}$ case are respectively illustrated in Fig. 5a and Fig. $5 \mathrm{~b}$.

Similar to the results in Hilton Head region, the inundation is less severe with the 5 LIDAR data than with the GEODAS. In the CAPES region, the inundation difference seems more pronounced than in the Hilton Head region with similar wind forcing. In the $30 \mathrm{~km} \mathrm{~h}^{-1}$ case, the inundation difference of LIDAR versus GEODAS is $123 \%$. This may be largely due to the fact that the land elevation in the CAPES is generally flatter than in the Hilton Head region, so the same vertical precision difference of LIDAR 10 versus GEODAS has more influence on the extent of inundation in the CAPES region. The inundation difference increases with the increasing of hurricane translation speed. This trend is shown in Table 2. For the hurricane moving at $20 \mathrm{~km} \mathrm{~h}^{-1}$, the difference is $66 \%$. As the moving speed increases to $35 \mathrm{~km} \mathrm{~h}^{-1}$, the difference grows to $156 \%$.

\section{Conclusion and discussion}

15 Significant inundation difference exists between the choices of LIDAR vs. GEODAS as the land elevation data employed in storm induced surge and inundation modeling for the two study regions. For Category 2-3 hurricanes with intensity ranges used in our model experiments, the maximum difference in the Hilton Head and the CAPES regions are respectively $67 \%$ and $156 \%$. The inundation difference decreases with decreasing

of hurricane translation speed or increasing of hurricane intensity. Generally, the vertical precision difference of the two land elevation databases may be the major reason for the inundation difference. Recently constructed man-made structures, not included in the GEODAS, but included in the LIDAR data sets may be another contributing reason. One has to keep in mind that, to some extent, the land elevation difference of the boundary as in Peng et al. (2006b). However, this relatively small storm surge difference may not be the major direct factor for so large inundation differences in the Hilton
OSD

4, 399-414, 2007

\section{LIDAR vs. GEODAS data in hurricane inundation modelling}

M. Peng et al.

\section{Title Page}

\section{Full Screen / Esc}

Printer-friendly Version

Interactive Discussion 
Head and the CAPES regions.

For high intensity hurricanes, coastal man-made structures could be overtopped by high surging water, so the inundation with GEODAS might not be so different from that with LIDAR. As a result, the inundation difference decreases as hurricane inten5 sity increases. Similar to the inverse relationship between inundation differences and hurricane translation speed is the effect of increasing the size of the hurricane or a slightly track tilting. As indicated in Peng et al. (2004) and Peng et al. (2006b), enlarging the RMW of the hurricane, or a compatible track tilting, is equivalent to an increase in hurricane intensity. All these may, to some extent, affect the inundation difference.

10 The results presented within the given representative hurricane intensity ranges display the substantial differences between using GEODAS vs. LIDAR as the land elevation data for hurricane induced inundation modeling. Further research is necessary to determine the generality of the study when more LIDAR data are available in other coastal regions.

15 Acknowledgements. This study is supported by the Carolina Coastal Ocean Observation and Prediction System (Caro-COOPS) project under NOAA Grant No. NA16RP2543 via the National Ocean Service, through Charleston Coastal Services Center. Caro-COOPS is a partnership between the University of South Carolina and North Carolina State University.

\section{References}

Falconer, R. A. and Owens, P. H.: Numerical simulation of flooding and drying in a depthaveraged tidal flow model, Proceedings Institution Civil Engineers, 83, 161-180, 1987.

Flather, R. A. and Heaps, N. S.: Tidal computations for Morecambe Bay. Geophys, J. R. Astronomical Soc., 42, 489-517, 1975.

Holland, G. J.: An analytic model of the wind and pressure profiles in hurricanes, Monthly Weather Rev., 108, 1212-1218, 1980.

Hubbert, G. D. and McInnes, K. L.: A storm surge model for coastal planning and impact studies, J. Coastal Res., 15(1), 168-185, 1999.
OSD

4, 399-414, 2007

\section{LIDAR vs. GEODAS data in hurricane inundation modelling}

M. Peng et al.

\section{Title Page}

\section{Full Screen / Esc}

Printer-friendly Version

Interactive Discussion 
Hsu, S. A. and Yan, Z.: A note on the radius of maximum wind for hurricanes, J. Coastal Res., 14(2), 667-668, 1998.

Large, W. G. and Pond, S.: Open ocean momentum fluxes in moderate to strong winds, J. Phys. Oceanogr., 11, 324-336, 1981.

5 Oey, L.-Y.: A wetting and drying scheme for POM, Ocean Modell., 9, 133-150, 2005.

Peng, M., L. Xie. and L. Pietrafesa., 2004: A numerical study of storm surge and inundation the Croatan-Albemarle-Pamlico Estuary System. Estuarine, coastal and shelf science 59, 121-137

Peng, M., Xie, L., and Pietrafesa, L.: Tropical cyclone induced asymmetry of sea level surge and fall and its presentation in a storm surge model with parametric wind fields, Ocean Modell., 14, 81-101, doi:10.1016/j.ocemod.2006.03.004, 2006a.

Peng, M., Xie, L., and Pietrafesa, L.: A Numerical Study on Hurricane Induced Storm Surge and Inundation in Charleston Harbor, South Carolina, J. Geophys. Res., 111, C08017, doi:10.1029/2004JC002755, 2006b.

Pietrafesa, L. J. and Janowitz, G. S.: The Hydrodynamics of CAPES, NOAA Technical Report, 86-11, 1986.

Powell, M. D., Vivkery, P. J., and Reinhold, T. A.: Reduced drag coefficient for high wind speeds in tropical cyclones, Nature, 422, 278-283, 2003.

Xie, L., Pietrafesa, L., and Peng, M.: Incorporation of a mass-conserving inundation scheme 20 into a three-dimensional storm surge model, J. Coastal Res., 20 1209-1223, 2004.

United States Geological Survey (USGS): Standards for Digital Elevation Models. National Mapping Program, Reston, VA, 1998.

OSD

4, 399-414, 2007

LIDAR vs. GEODAS data in hurricane inundation modelling

M. Peng et al.

\section{Title Page}

Abstract

Conclusions

References

Tables

Figures
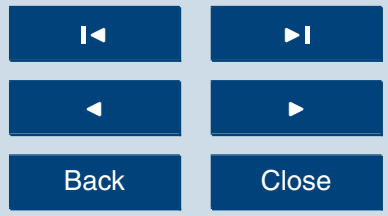

Back

Close

Full Screen / Esc

Printer-friendly Version

Interactive Discussion 
Table 1. The model simulated inundation grid point numbers in Hilton Head region with LIDAR and GEODAS land elevation data. Different hurricane intensities are assumed in the experiments. The translation speed and RMW for all hypothetical hurricanes are respectively $30 \mathrm{~km} \mathrm{~h}^{-1}$ and $50 \mathrm{~km}$.

\begin{tabular}{cccc}
\hline Central Pressure $(\mathrm{mb})$ & LIDAR $(\mathrm{L})$ & GEODAS $(\mathrm{G})$ & $(\mathrm{G}-\mathrm{L}) / \mathrm{L} \times 100 \%$ \\
\hline 965 & 19972 & 33386 & $67 \%$ \\
960 & 22849 & 35016 & $53 \%$ \\
955 & 25748 & 35983 & $40 \%$ \\
950 & 29036 & 36316 & $25 \%$ \\
945 & 33212 & 36679 & $10 \%$ \\
\hline
\end{tabular}

\section{LIDAR vs. GEODAS} data in hurricane inundation modelling

M. Peng et al.

\section{Title Page}

\section{Abstract}

Introduction

Conclusions

References

Tables

Figures
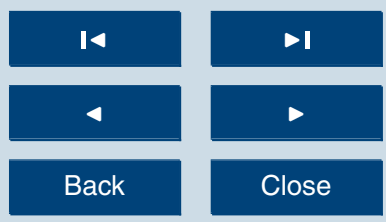

Back

Close

Full Screen / Esc

Printer-friendly Version

Interactive Discussion 
OSD

4, 399-414, 2007

\section{LIDAR vs. GEODAS} data in hurricane inundation modelling

M. Peng et al.

Table 2. The model simulated inundation grid point numbers in the CAPES region with different hurricane translation speed. The hurricane's central pressure and RMW are respectively $960 \mathrm{mb}$ and $50 \mathrm{~km}$.

\begin{tabular}{cccc}
\hline Moving Speed $\left(\mathrm{km} \mathrm{h}^{-1}\right)$ & LIDAR (L) & GEODAS $(\mathrm{G})$ & $(\mathrm{G}-\mathrm{L}) / \mathrm{L} \times 100 \%$ \\
\hline 20 & 8973 & 14920 & $66 \%$ \\
25 & 6781 & 13572 & $100 \%$ \\
30 & 4979 & 11113 & $123 \%$ \\
35 & 4082 & 10449 & $156 \%$ \\
\hline
\end{tabular}

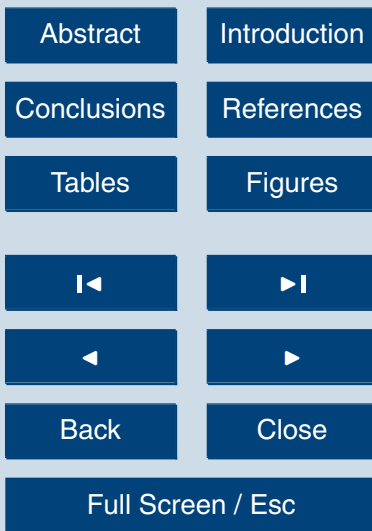

Printer-friendly Version

Interactive Discussion 

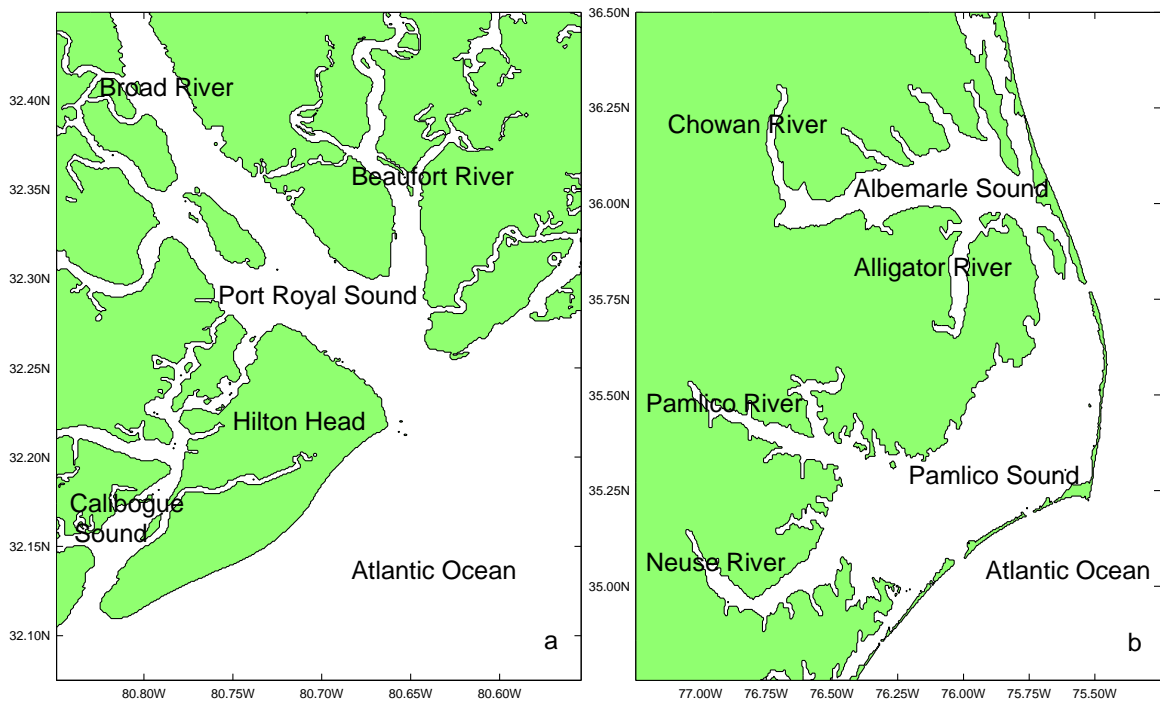

LIDAR vs. GEODAS data in hurricane inundation modelling

M. Peng et al.

\section{Title Page}

Abstract

Introduction

Conclusions

References

Tables

Figures

14

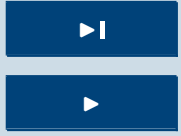

Back

Close

Fig. 1. The location of the two study regions. (a) Hilton Head. (b) the CAPES.

Full Screen / Esc

Printer-friendly Version

Interactive Discussion

EGU 
OSD

4, 399-414, 2007
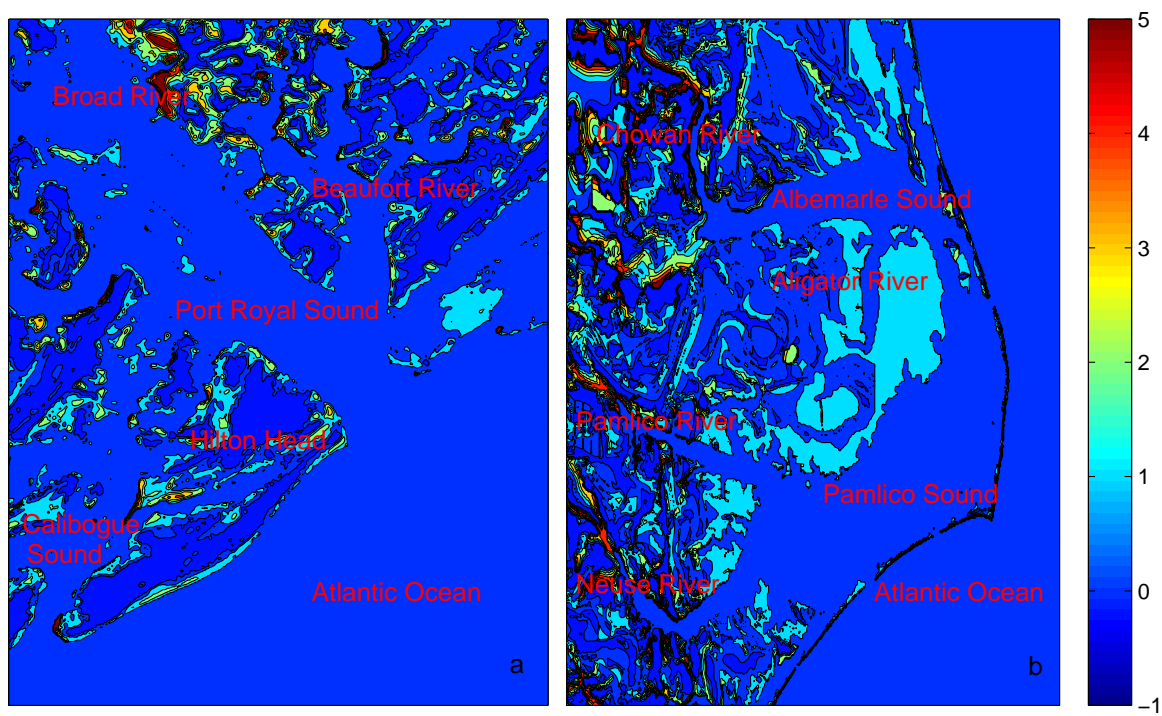

Fig. 2. The land elevation difference (LIDAR - GEODAS) in Hilton Head and the CAPES regions. The unit is in meter.
LIDAR vs. GEODAS data in hurricane inundation modelling

M. Peng et al.

Title Page

Abstract

Introduction

Conclusions

References

Tables

Figures

14

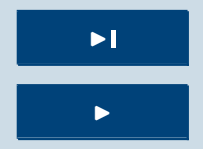

Back

Close

\section{Full Screen / Esc}

Printer-friendly Version

Interactive Discussion 

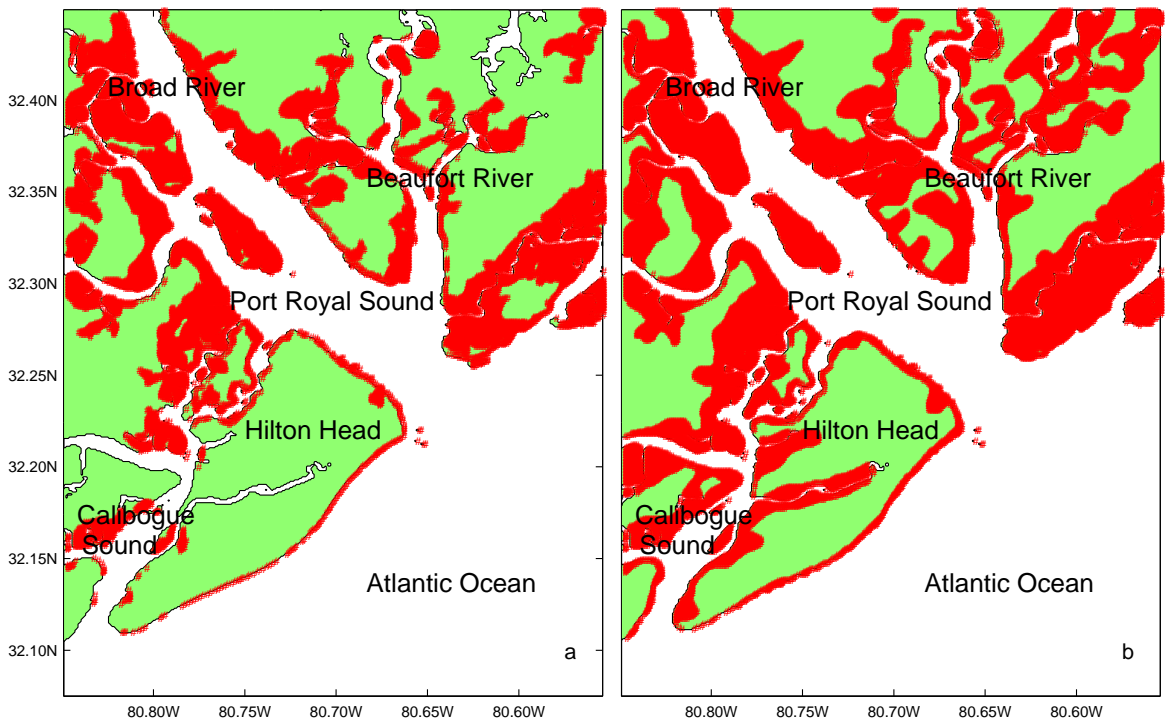

\section{LIDAR vs. GEODAS data in hurricane inundation modelling}

M. Peng et al.

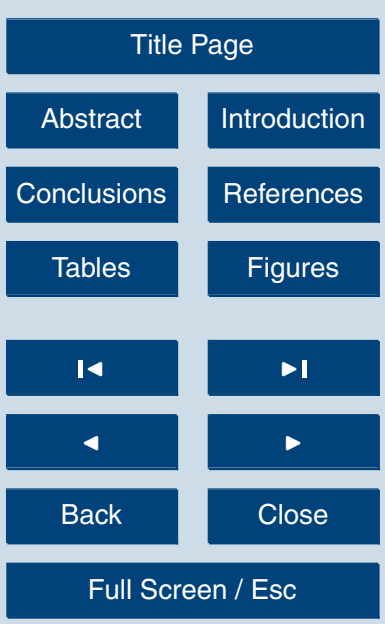

Fig. 3. The inundation difference with $965 \mathrm{mb}$ as the hypothetical hurricane central pressure. The hurricane makes landfall at Hilton Head Island with northwestward moving direction. The translation speed is $30 \mathrm{~km} \mathrm{~h}^{-1}$, and the RMW is $50 \mathrm{~km}$. Red color indicates inundated area. Panels (a) and (b) are respectively for LIDAR and GEODAS cases.

Printer-friendly Version

Interactive Discussion 
OSD

4, 399-414, 2007
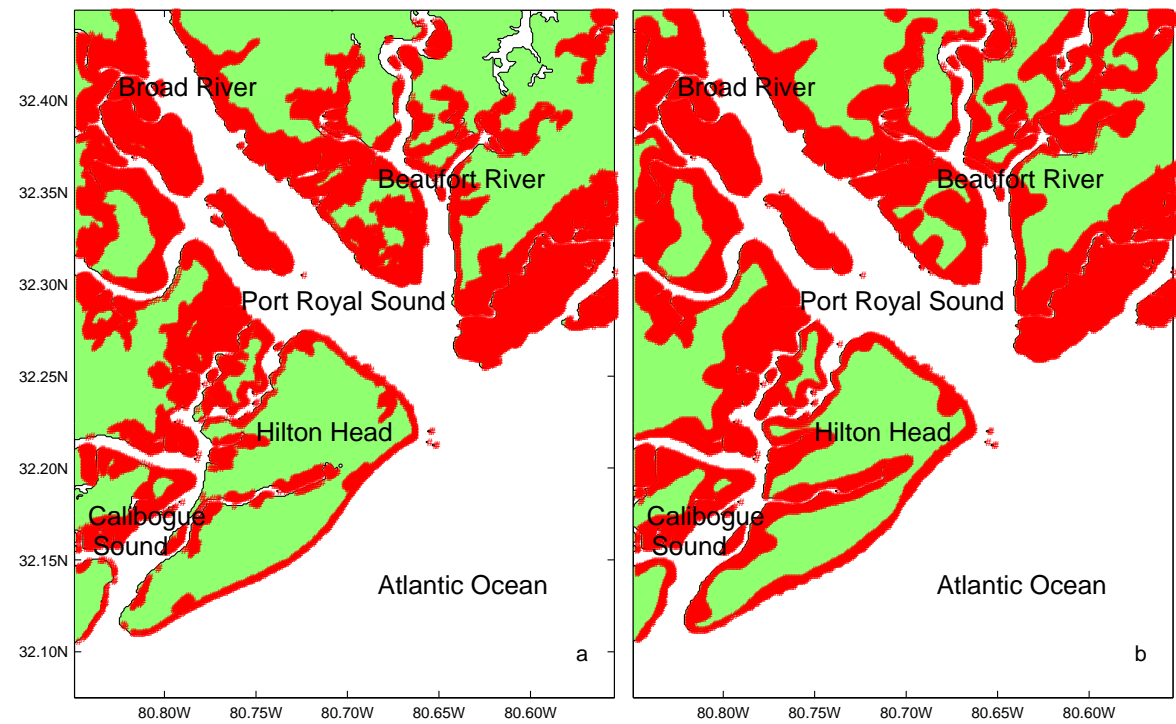

Fig. 4. Same as Fig. 3, except that the hurricane central pressure is $950 \mathrm{mb}$.

\section{LIDAR vs. GEODAS} data in hurricane inundation modelling

M. Peng et al.

\section{Title Page}

\section{Abstract}

Introduction

Conclusions

References

Tables

Figures
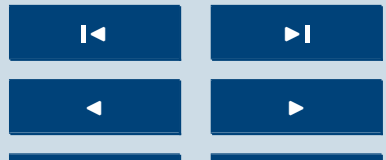

Back

Close

\section{Full Screen / Esc}

Printer-friendly Version

Interactive Discussion

EGU 

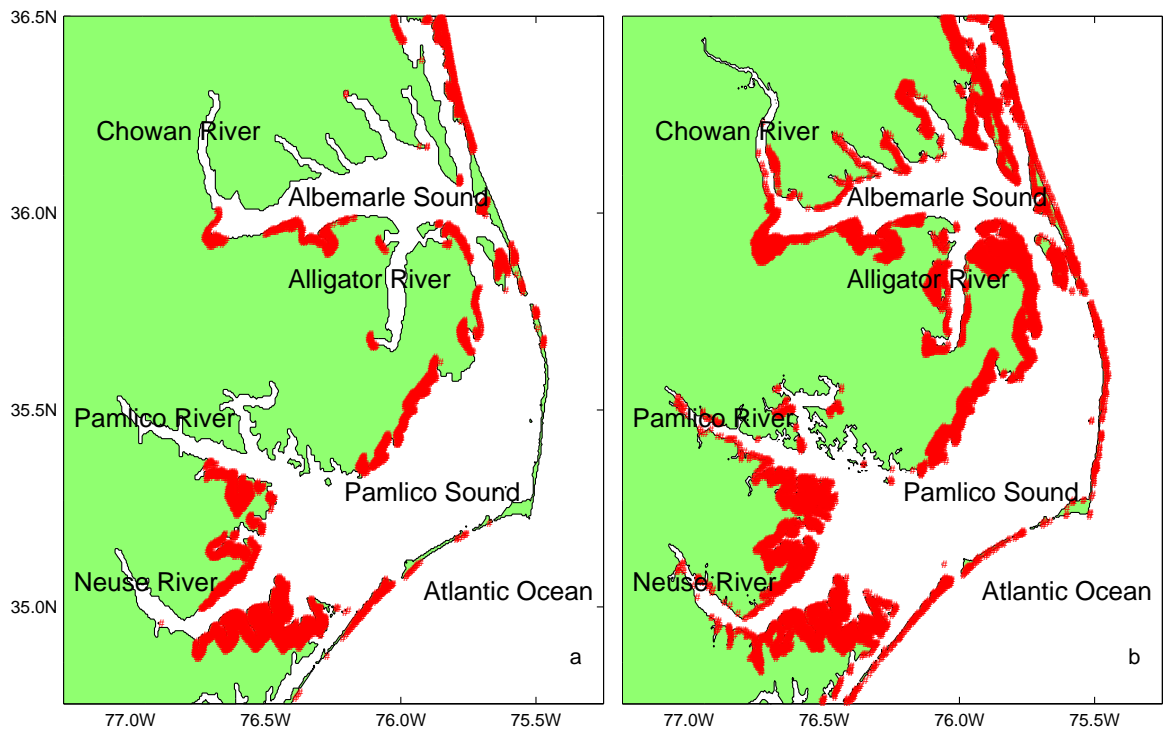

\section{LIDAR vs. GEODAS data in hurricane inundation modelling}

M. Peng et al.

\section{Title Page}

\section{Abstract}

Introduction

Conclusions

References

Tables

Figures
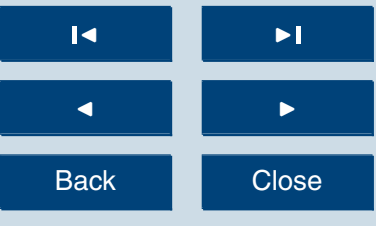

Back

Close

\section{Full Screen / Esc}

The hurricane moves northward along $76.0^{\circ} \mathrm{W}$. The translation speed is $30 \mathrm{~km} \mathrm{~h}$
$\mathrm{RMW}$ is $50 \mathrm{~km}$. Panels (a) and (b) are respectively for LIDAR and GEODAS cases.

Printer-friendly Version

Interactive Discussion 